\title{
Junior College Libraries: Needs and Prespectives
}

\author{
A CONFERENCE OF THE \\ JUNIOR COLLEGE LIBRARIES SECTION \\ ASSOCIATION OF COLLEGE AND RESEARCH LIBRARIES \\ A DIVISION OF THE \\ AMERICAN LIBRARY ASSOCIATION
}

\section{Cosponsored by:}

American Association of Junior Colleges

Clearinghouse for Junior College Information, University of California, Los Angeles

School of Library Services, University of California, Los Angeles

Dates: June 2I-24, 1967

Place: University of California, Los Angeles

Program:

Wednesday, June 21

3:00 p.m. Registration

6:30 p.m. Dinner

"Defining the need"

Keynote speaker

Panel discussion

Thursday, June 22-"Meeting the need"-panel discussions

9:00 a.m. Instructional support

10:30 a.m. Library material and resources

12:00 noon Lunch

Clearinghouse on Junior College Information

2:00 p.m. Library personnel

Speaker-"What are the needs"

Panel-"Developing personnel resources-role of the library school "

6:30 p.m. Dinner

Speaker-“Innovation and Automation"

8:30 p.m. Equipment demonstration

Friday, June 23

9:00 a.m. Visitation and tours to selected Junior College libraries

Luncheon to be served on the Junior College campus

6:30 p.m. Dinner

Saturday, June 24

9:30 a.m. "Building and equipment: development and evaluation"speaker and panel discussion

Rooms will be available in the dormitories at UCLA for the nights of June 21-23. The conference fee will be announced in a future issue of "CRL News" and will include all expenses for scheduled functions. Registration is open to administrators, librarians, and instructional personnel, but will be limited.

Additional information and registration forms will be available from the ACRL Executive Secretary, 50 E. Huron Street, Chicago 60611 after April 1. A mailing will be made to all members of the Junior College Libraries Section at that time and will include registration forms. 